\title{
Spatial organisation of macrozoobenthic communities in response to environmental factors in a coastal lagoon of the NW African coast (Merja Zerga, Morocco)
}

\section{Organisation spatiale des communautés macrozoobenthiques en réponse aux facteurs de l'environnement dans une lagune côtière du NW africain : Merja Zerga, Maroc}

\author{
Hocein Bazaïri $^{\mathrm{a}}$, Abdellatif Bayed ${ }^{\mathrm{b}, *}$, Michel Glémarec ${ }^{\mathrm{c}}$, Christian Hily ${ }^{\mathrm{c}}$ \\ ${ }^{a}$ Faculté des Sciences, Département de Biologie, Unité de Biologie et Ecologie Marines, Université Hassan II Aïn Chock, \\ B.P. 5366, Maârif, 20100 Casablanca, Morocco \\ ${ }^{b}$ Unité d'Océanologie Biologique, Institut Scientifique, Université Mohammed V-Agdal, B.P. 703, Agdal, 10106 Rabat, Morocco \\ ${ }^{c}$ Laboratoire des Sciences de l'Environnement Marin, Institut Universitaire Européen de la Mer, Place Nicolas Copernic, \\ Université de Bretagne Occidentale, 29280 Plouzané, France
}

Received 5 November 2002; received in revised form 21 February 2003; accepted 24 February 2003

\begin{abstract}
Merja Zerga lagoon, located on the Moroccan Atlantic coast, is a site of international value (Ramsar Site) in terms of its ornithological diversity. However, the lagoon is heavily exploited for its clams and fishes. In an effort to further understanding of lagoon ecosystems, and thus to facilitate the management and conservation of their resources, an ecological survey of its benthic component was carried out. Benthos is a valuable food source for birds, fishes and humans. This work involved identifying the macrozoobenthic communities in the lagoon and assessing their spatial distribution. The study was based on monthly sampling of the intertidal zone and seasonal sampling in subtidal zone, over a one-year period. In the intertidal zone, salinity and median diameter and silt content of the sediment exhibited a gradient extending from the entrance to the inner lagoon, according to tidal flow. Sediment grain size characteristics reflected a gradual decrease of tidal currents from the lagoon entrance towards the inner parts of the lagoon, i.e. silt content increased with distance from the entrance. In the subtidal zone, the tidal currents were fairly strong throughout the lagoon, leading to the presence of coarser sediments than in the intertidal zone. Based on these physical, chemical and substratum characteristics, three communities were identified: (i) Cerastoderma edule and (ii) Scrobicularia plana communities were located in both the intertidal and subtidal zones; and (iii) a Tapes decussata community that was only found in the subtidal zone. The assemblages in the subtidal zone were more diverse and the mean abundances of the constituent species were higher than in the intertidal zone, which is an interesting feature for a lagoon environment. Communities were distributed along an ecological gradient, without showing a discontinuity or ecotone. The lagoon functioned like an estuary in which the community structure was controlled by edaphic factors in the intertidal zone, and by the hydrological factors in the subtidal zone.
\end{abstract}

(C) 2003 Éditions scientifiques et médicales Elsevier SAS and Ifremer/CNRS/IRD. Tous droits réservés.

\section{Résumé}

La lagune de Merja Zerga, située sur la côte atlantique marocaine, présente un intérêt international (Site Ramsar) pour sa diversité ornithologique. Toutefois, elle est très exploitée pour ses palourdes et ses poissons. Dans le but de bien connaitre le fonctionnement de l'écosystème lagunaire pour aider à sa gestion et la conservation de ses ressources, un suivi écologique a été mené sur l'écosystème benthique, compartiment-proie essentiel pour les oiseaux et pour l'homme. Ce travail vise à identifier les communautés macrozoobenthiques et à préciser leur répartition spatiale. L'étude est basée sur un échantillonnage mensuel de la zone intertidale et sur des prélèvements saisonniers de la zone subtidale, sur une période d'une année. En zone intertidale, la salinité, la médiane granulométrique et les taux de pélites présentent des

\footnotetext{
* Corresponding author. Tel.: +212-37-77-45-48; fax: +212-37-77-45-40.

E-mail address: bayed@israbat.ac.ma (A. Bayed).
} 
gradients allant de l'ouverture vers l'intérieur de la lagune, en suivant le flot engendré par la marée. Les caractéristiques granulométriques traduisent l'affaiblissement progressif des courants de marée de l'aval à l'amont, i.e. les teneurs de pélites augmentent en s'éloignant de l'ouverture. En zone subtidale, les courants de marée restent assez forts tout au long de la lagune, ce qui conduit à la présence de sédiments plus grossiers qu'en zone intertidale. Selon ce schéma de structure physico-chimique et édaphique, trois communautés sont identifiées : les communautés à (i) Cerastoderma edule et à (ii) Scrobicularia plana, localisées à la fois en zones intertidale et subtidale et (iii) une communauté à Tapes decussata, présente uniquement en zone subtidale. Les assemblages sont plus diversifiés en zone subtidale et les abondances moyennes des espèces y sont plus fortes qu'en zone intertidale, ce qui constitue une originalité pour un milieu lagunaire. Les communautés se distribuent le long d'un gradient écologique sans stade de transition ou écotone. La lagune fonctionne selon un modèle estuarien dans lequel la structure des communautés est contrôlée par les facteurs édaphiques en zone intertidale et par les facteurs hydrologiques en zone subtidale.

(C) 2003 Éditions scientifiques et médicales Elsevier SAS and Ifremer/CNRS/IRD. Tous droits réservés.

Keywords: Intertidal; Subtidal; Brackish water environments; Macrozoobenthic biodiversity; Ecological succession

Mots clés : Intertidal ; Subtidal ; Eaux saumâtres ; Biodiversité du macrozoobenthos ; Succession écologique

\section{Introduction}

Littoral ecosystems such as lagoons and estuaries are often thought as being fragile, young and highly productive (Amanieu et al., 1980). Because of such ecological characteristics, conflicts are expected to arise between their exploitation and the protection of natural resources. A sound understanding of their structure and functioning is therefore necessary to implement effective management and conservation measures. In Morocco, as elsewhere, the increase of human activities on the coast has led to various environmental pressures such as the overexploitation of natural resources, the construction of ports, dredging and dumping of organic and mineral wastes. The benthic macrofauna of the lagoon is a natural resource having primordial importance, since it includes both species of great economic value and a large number of species that serve as food for the avifauna and the ichthyofauna. The benthic macrofauna is also a good indicator of the variability of the environmental conditions. Indeed, the macrobenthic fauna is highly correlated with the ecological conditions prevailing at the sediment-water interface where multiple effects of organic enrichment and pollution occur (Glémarec, 1986). Thus, the benthic macrofauna is one of the best biological tools available for reflecting environmental change (Le Bris and Glémarec, 1996).

As the dilution and dispersion of the continental inputs are of lesser strength than in open environments, lagoons are particularly vulnerable. Thus, in order to develop sound management policies, baseline surveys describing both the abiotic and biotic components, as well as their reciprocal interactions, are needed.

Merja Zerga lagoon is located along the Moroccan Atlantic coast and is an example of a vulnerable coastal ecosystem. With respect to the international value of its avifauna, the lagoon was declared a protected area in 1978. It is also one of the four Moroccan sites selected by the Ramsar Convention on the Conservation of Wetlands of International Importance.

Among wetland areas in Morocco, the Merja Zerga lagoon has also been identified as a key site for migrating waterfowl from the Palaearctic zone. Recent reviews on wintering anatidaes (El Agbani, 1997) and waders (Qninba, 1999) in Morocco have shown that Merja Zerga is the most important national site for these birds. According to the authors, three species of ducks and eight species of waders can be found in numbers exceeding designation criteria according to their international importance (criteria 5 and 6 of the Ramsar Convention).

Merja Zerga lagoon is also strategically located along the vast biogeographic gradient of eastern Atlantic lagoon ecosystems that spans from north-western Europe to the tropical African coast. Recently, a number of environmental issues have been raised. These include the overexploitation of natural living resources (clams and fish), the transformation of the watershed region for agricultural purposes, the discharge of water from rice fields into the lagoon and the development of a seaside resort at Moulay Bousselham.

Studies on the benthic macrofauna of Merja Zerga lagoon are scarce and ecological information is lacking. Thus, the objectives of the present study involved establishing a baseline, based on a survey of the macrobenthic assemblages and identifying the environmental factors driving the structure and the functioning of the benthic communities.

\section{Materials and methods}

\subsection{Study site}

The Merja Zerga lagoon, known also as Moulay Bousselham lagoon, is the most northern coastal lagoon along the Atlantic Moroccan coast and is located approximately $120 \mathrm{~km}$ north of Rabat Fig. 1. The lagoon is elliptical in shape, covers an area of approximately $30 \mathrm{~km}^{2}$ and is subdivided into two basins of unequal size: the Merja Kahla (translated as Black Lagoon, according to the black colour of the bottom, which is visible through the low depth) basin to the north and the Merja Zerga (translated as Blue Lagoon, in relation to the water colour as the depth is higher than in Merja Kahla) basin to the south. The water of the lagoon has two origins: oceanic, through tidal action, and continental 


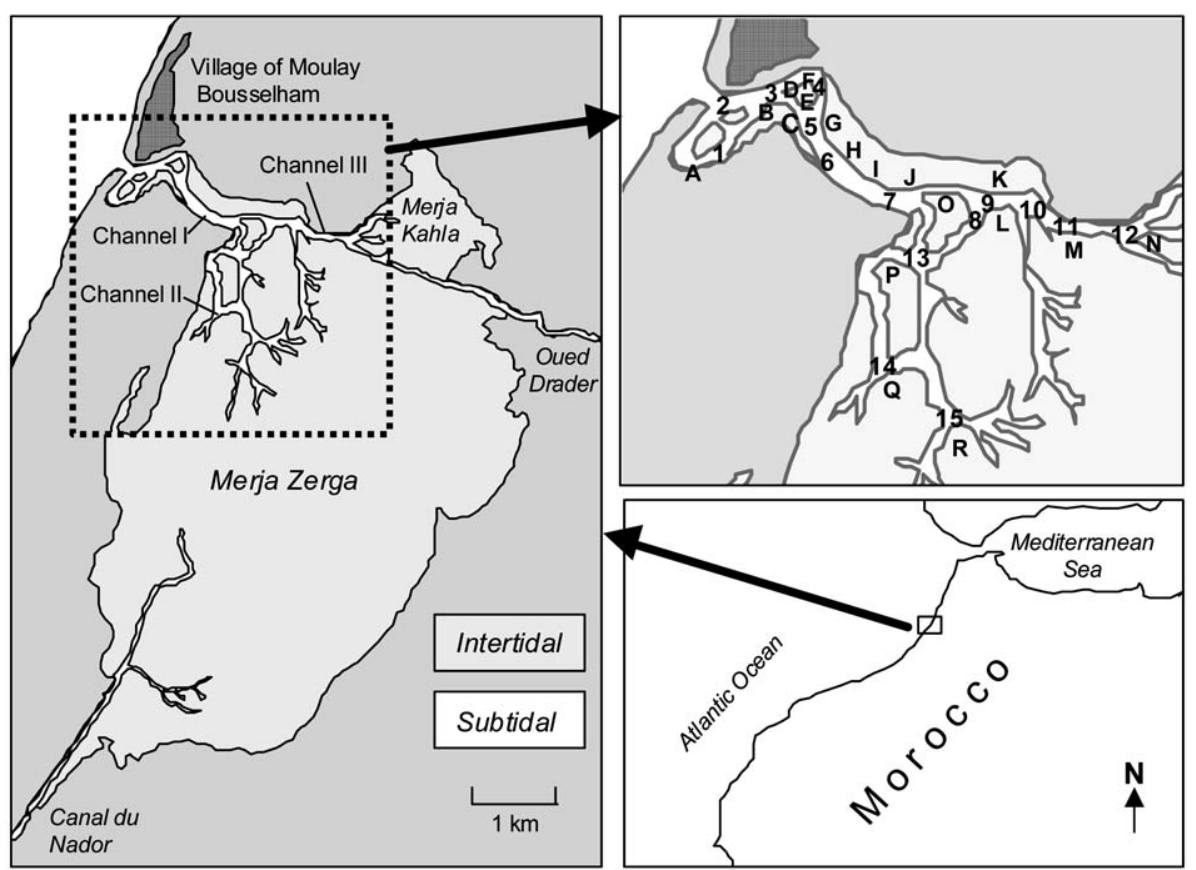

Fig. 1. Map showing the location of Merja Zerga lagoon and intertidal (letters A to R) and subtidal (numbers 1-15) sampling stations.
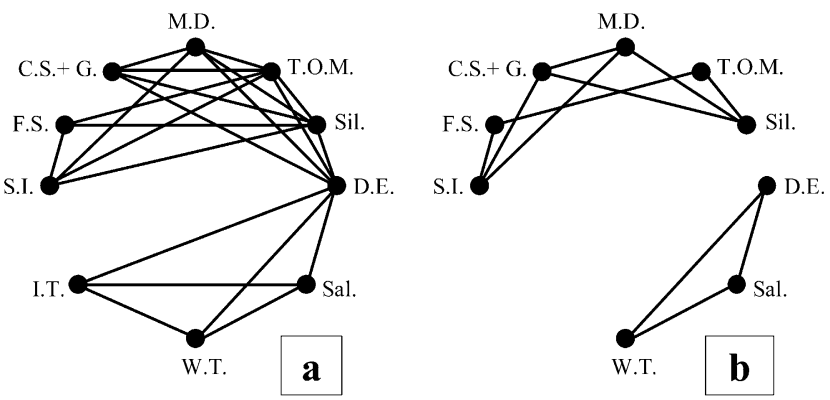

Fig. 2. Representation (around a circle) of the results of correlation tests between the various abiotic measures. The lines indicate significant correlation at the $95 \%$ level. D.E., distance of stations from the entrance; Sil., silts; T.O.M., total organic matter; M.D., median diameter; C.S. + G., coarse sand + gravels; F.S., fine sand; S.I., sorting index; I.T., = interstitial temperature; W.T., water temperature; Sal., salinity.

through the input of two permanent freshwater tributaries, namely the Oued Drader to the east and the Canal du Nador to the south. The filling and emptying of the lagoon occurs via a network of permanent channels, which can be grouped into three categories: the main channel (channel I), secondary channels (channel II) and the tertiary channels (channel III) (see Fig. 1). The place where the lagoon meets the ocean consists of a narrow channel which is delimited by a rocky shallow reef to the north and a sand bar to the south. The sand bar controls the size of the entrance and, as a result, exchanges of water between the lagoon and the ocean. Its rapid spread towards the north or the south, which might completely seal off the entrance, occurs on a regular basis (Beaubrun, 1976). The last time the entrance was closed off was in 1991. On such occasions, reopening of the entrance is made artificially by the local inhabitants.

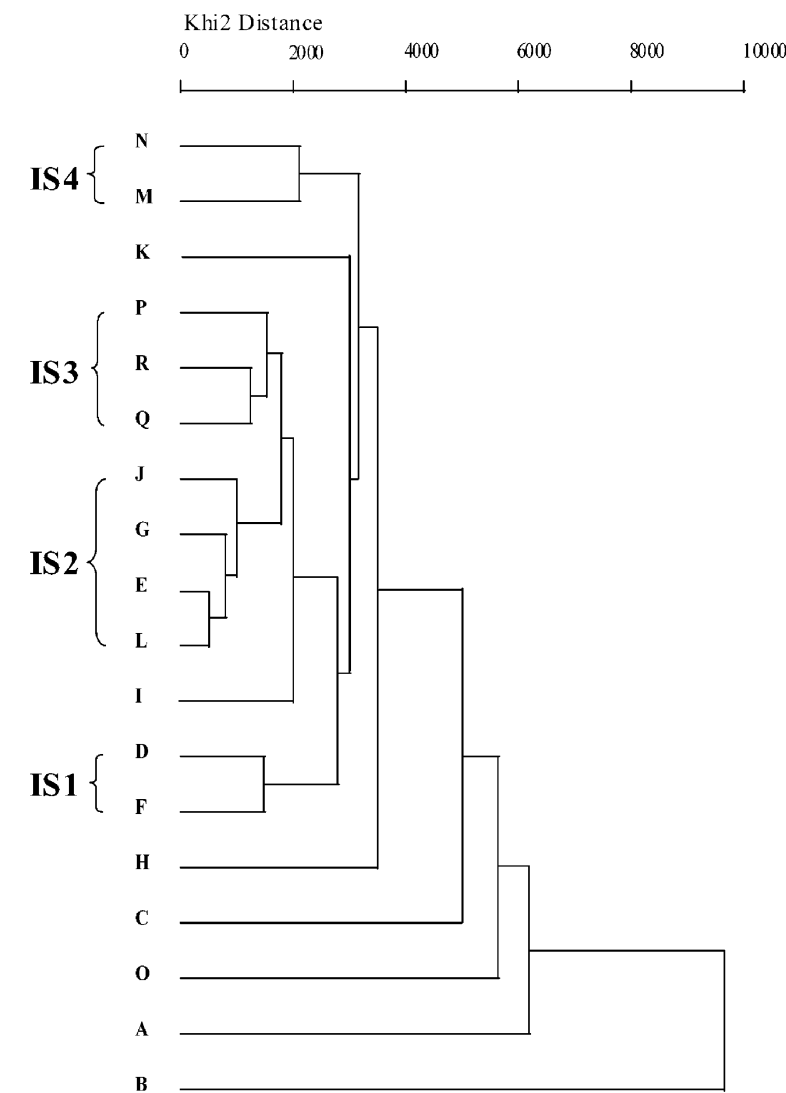

Fig. 3. Dendrogram produced from hierarchical cluster analysis, carried out on intertidal assemblage data. Four clusters are recognised (IS1, IS2, IS3 and IS4).

Tides are semi-diurnal. The mean tidal range $(0.15-$ $1.15 \mathrm{~m}$ ) allows the lagoon to be categorised as a microtidal environment (Carruesco, 1989). At high tide, the lagoon is 


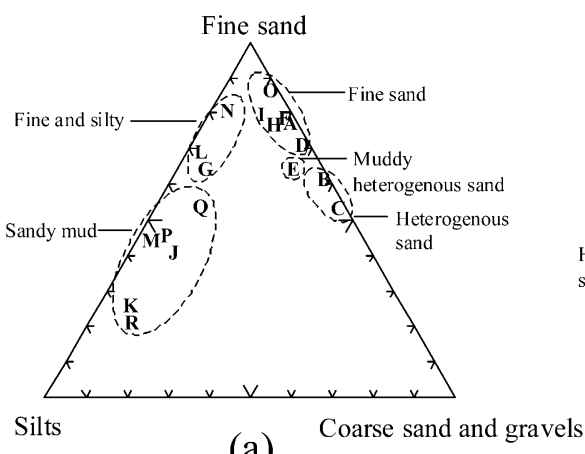

(a)

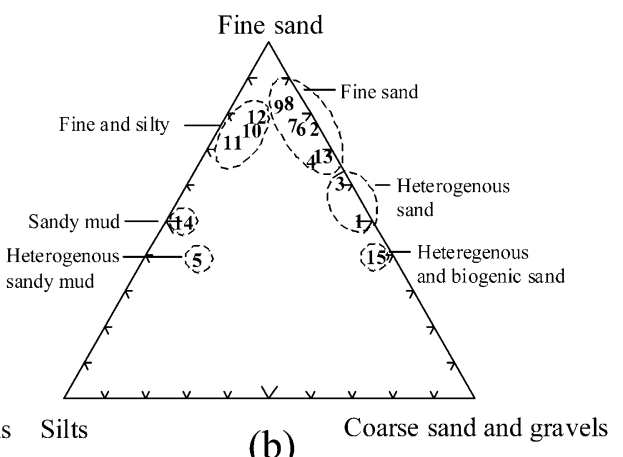

(b)

Fig. 4. Triangular diagram used to characterise the intertidal (a) and subtidal (b) sampling stations in function of three granulometric fractions: fine sand, silts and combined coarse sand and gravels.

completely flooded. At low tide, the Merja Kahla is completely empty of water whereas the Merja Zerga retains water within its channels. Hydrological data reveal that continental waters generally contribute to between $1 \%$ and $2 \%$ of the waters passing through the lagoon (Carruesco, 1989). A number of situations arise, however, as a function of the relationship between oceanic and continental influences, which lead to seasonal variability of the saline regime within the lagoon. This allows the lagoon to be categorised as an "estuarine lagoon" with mixohaline waters in winter and as a "neuter lagoon" with euhaline waters in summer (Carruesco, 1989). The salinity fluctuations throughout the year generally depend on the closure and reopening of the sand bar and thus on the flow of seawater into the lagoon. The complete closure of the entrance leads to distinctive hydrological conditions that bring about a marked drop in salinity throughout the lagoon. However, such conditions are scarce and of relatively short duration as the local inhabitants reopen the passage promptly. Water temperatures within the lagoon range from 27 to $28{ }^{\circ} \mathrm{C}$ in summer and from 13 to $15^{\circ} \mathrm{C}$ in winter. The shallow depths and the location of the lagoon behind a coastal dune, that shelters it from the dominant northern and western winds, explain the high summer temperatures of water.

Two main sedimentary structures can be identified within the lagoon (Bidet et al., 1977). The first, which is sandy, is primarily of oceanic origin. Its presence is linked to wave and tidal current action. Sand is deposited primarily during flood tide in those regions subject to high-energy conditions. The second, which is silty, is found in the more sheltered area of the lagoon. The origin of silt is continental through the input of fine particulate matter from the Oued Drader and the Canal du Nador. During strong winter floods, run-off from the banks also contributes to the input of silt into the lagoon. The predominance of either of these two sediment types varies as a function of both the hydrodynamic and morphological conditions prevailing in the lagoon, and on the climatic fluctuations (Bidet et al., 1977). Sediment cores taken from the lagoon (Bidet et al., 1977) revealed a marked succession of terrestrial and marine sedimentary facies. According to the authors, this superposition of facies is a result of the limits shifting of marine and terrestrial influences during the recent Quaternary.

\subsection{Sampling and sample analyses}

Within the intertidal zone, 18 stations (A to R in Fig. 1 were sampled monthly from February 1994 to February 1995. The sampling was realised using a spade and each sample had a surface area of $0.25 \mathrm{~m}^{2}$ to a depth of $20 \mathrm{~cm}$. Within the subtidal zone, 15 stations (1-15) were sampled seasonally: in April 1994 (spring), in July 1994 (summer), in October 1994 (autumn) and in January 1995 (winter). In the subtidal, semi-quantitative samples were taken using a dredge very similar to the one used by Picard (1965) but modified in order to extract sediment quickly to a depth of $15 \mathrm{~cm}$. The main characteristics of the dredge are described in Elkaim (1976a) who successfully used this sampling apparatus in the Bou Regreg estuary. Both types of samples were sieved in situ using a $1 \mathrm{~mm}$ mesh. The material retained on the mesh was fixed in $8 \%$ formalin. In the laboratory, the material was sorted and the macrofauna identified and counted. Most of the benthic organisms were identified to the species level.

Each faunal sampling was coupled with the measurement of abiotic parameters. In the intertidal zone, the temperature of the sediment was taken at a depth between 5 and $10 \mathrm{~cm}$. Water temperature and salinity were measured in the channel near the sampled stations at a depth of $20 \mathrm{~cm}$. In the subtidal zone, the measurements were made close to the bottom.

For each station, a sediment sample was taken to determine the diameter grain size and to estimate the ash-free dry weight of the total organic matter present in the sediment (furnace $450^{\circ}, 6 \mathrm{~h}$ ). Taking into account three fractions (fine particle or silt $(\varnothing<63 \mu \mathrm{m})$, fine sand $(63 \mu \mathrm{m}<\varnothing<500 \mu \mathrm{m})$ and combined coarse sand-gravels $(\varnothing>500 \mu \mathrm{m})$ ), each station was placed in a triangular diagram (Shepard, 1954) (e.g. Fig. 4. Different groups of stations on this diagram are classed according to the biosedimentary classification of Chassé and Glémarec (1976). 


\subsection{Data analysis}

Abiotic factors were studied using a Bravais-Pearson correlation analysis, firstly in a paired parameters test, and secondly between these parameters and the distance of the stations from the entrance. The mean value for each parameter was calculated over a complete annual cycle. The significant correlation between a given parameter and the distance from the entrance indicates a spatial evolution of this parameter interpreted as a gradient from the entrance to the inland part of the lagoon.

Macrozoobenthic assemblages were based on groups of stations identified by combining two ordination methods, an ascending hierarchical classification (AHC) method (Lebart et al., 1982) using the interstation Chi-square distance and the weighted mean distances as a criterion of aggregation, and a factorial correspondence analysis (FCA; Benzecri, 1973). These two ordination methods were performed on the same station/species matrix. The data set used was the abundance of each species compared to its annual maximum (Dakki, 1985). The coefficient was calculated as follows (maximum method): instead of using the mean annual abundance, the maximum annual abundance was used. As demonstrated by Dakki (1985), the coefficient best describes the biotope occupation capacity of a given species. It has been successfully used to describe the biotypology of both sand beach ecosystems along the Atlantic Moroccan coast (Bayed, 2003) and mollusc assemblages in the Merja Zerga lagoon (Bazairi and Bayed, 1998). The method allows an equal importance to be given to species exhibiting single cohort generations and to species exhibiting polymodal generations and low abundance. The maximum method thus favours those species with a short cycle and a fast turnover as opposed to species with small abundance fluctuations and which are relatively scarce. The Frequency $\times$ Mean Dominance index (FDM; Glémarec, 1964) was calculated for each species in each identified assemblage. The assemblages structure was studied through the calculation of species richness $(S)$, abundance $(A)$, the Shannon-Weaver diversity index $H^{\prime}$ and the Pielou evenness index $J^{\prime}$. The Dimo model (Quinghong, 1995) describes, in a single graphic representation, the species richness $\log _{2}(S)$, the Shannon $H^{\prime}$ diversity index, the evenness $J^{\prime}$ (Pielou $H^{\prime} / \log _{2}(S)$ and Quinghong $Q$ index, where $Q=H^{\prime} / \sin (a)$. This index is defined as being the vector length from the origin to the point of the station.

Functional structure analysis is based on the knowledge of etho-ecological groups or trophic guilds. Here, the Hily and Bouteille (1999) classification was used. It focuses on the nature and origin of food, the behaviour used to catch food, and the exploited microhabitats. According to the food size, the first four groups are macrophagous, the last four microphagous:

- herbivores $(\mathrm{H})$ : feeding on macroalgae and/or phanerogams;

- scavengers $(\mathrm{N})$ : feeding on carrion;
- detritic feeders (Dt): feeding on macrodetritus (mainly decaying macrophytes);

- predators $(\mathrm{C})$ : feeding on mobile or sessile animals;

- suspension feeders (S): feeding on fine suspended organic particles in the water column;

- selective deposit feeders (DS): feeding on fine selected deposit particles at the sediment surface;

- non-selective deposit feeders (DSS): feeding on mixture of fine particles at the sediment subsurface;

- micrograzers $(\mu \mathrm{B})$ : feeding on surface attached living microorganisms and biofilm.

\section{Results}

\subsection{Spatial organisation of the habitat}

The tests performed between the different abiotic parameters reveal that, in the intertidal zone, there was significant correlation Fig. 2 between the distance of the stations from the lagoon entrance (mouth) and both the particle size and hydrological characteristics. In the subtidal zone, only the temperature and salinity parameters were correlated with the distance to the entrance.

\subsection{Ecological gradients}

\subsubsection{Intertidal zone}

In the intertidal zone, $\mathrm{AHC}$ and FCA were performed after rare taxa were removed (Bachelet et al., 1996). The data matrix was composed of 61 species (observations) and 18 stations (variables). The method produced four groups of stations Fig. 3). The first group (IS1) included the stations located in the vicinity of the lagoon mouth (D and F), characterised by fine sands (median grain size between 220 and $390 \mu \mathrm{m}$ ). The stations in the IS2 group were located along the main channel and contained a variable amount of silt material: station $\mathrm{E}$ was characterised by muddy heterogeneous sand, whereas the sediment was fine and silty at stations $G$ and $\mathrm{L}$ and sandy mud at station $\mathrm{J}$ (Fig. 4). The two remaining groups were also characterised by muddy sands. Stations P, $\mathrm{Q}$ and R (IS3 group) were characterised by muddy sand and were located along the secondary channel. Stations M and N (IS4 group), characterised, respectively, by muddy sand and fine silty were located upstream of the main channel, in the vicinity of the mouth of Oued Drader.

These various groups of stations, as identified by the cluster analysis, were clearly differentiated in the factorial plan $\mathrm{F} 1 \times \mathrm{F} 2$ of the correspondence analysis, performed on the same data matrix Fig. 5. The Gutmann effect was detected where the plot takes a parabolic shape, demonstrating that the F2 axis is a quadratic function of the F1 axis. Along the positive values of the F1 axis, the polychaetes Scoloplos armiger and Ophelia bicornis display the higher weighting (23.5\% and $19.2 \%$, respectively), whereas the bivalve Cerastoderma edule and the polychaete Nephtys cirrosa show lower weighting values (14.4\% and $5.9 \%$, respectively). 


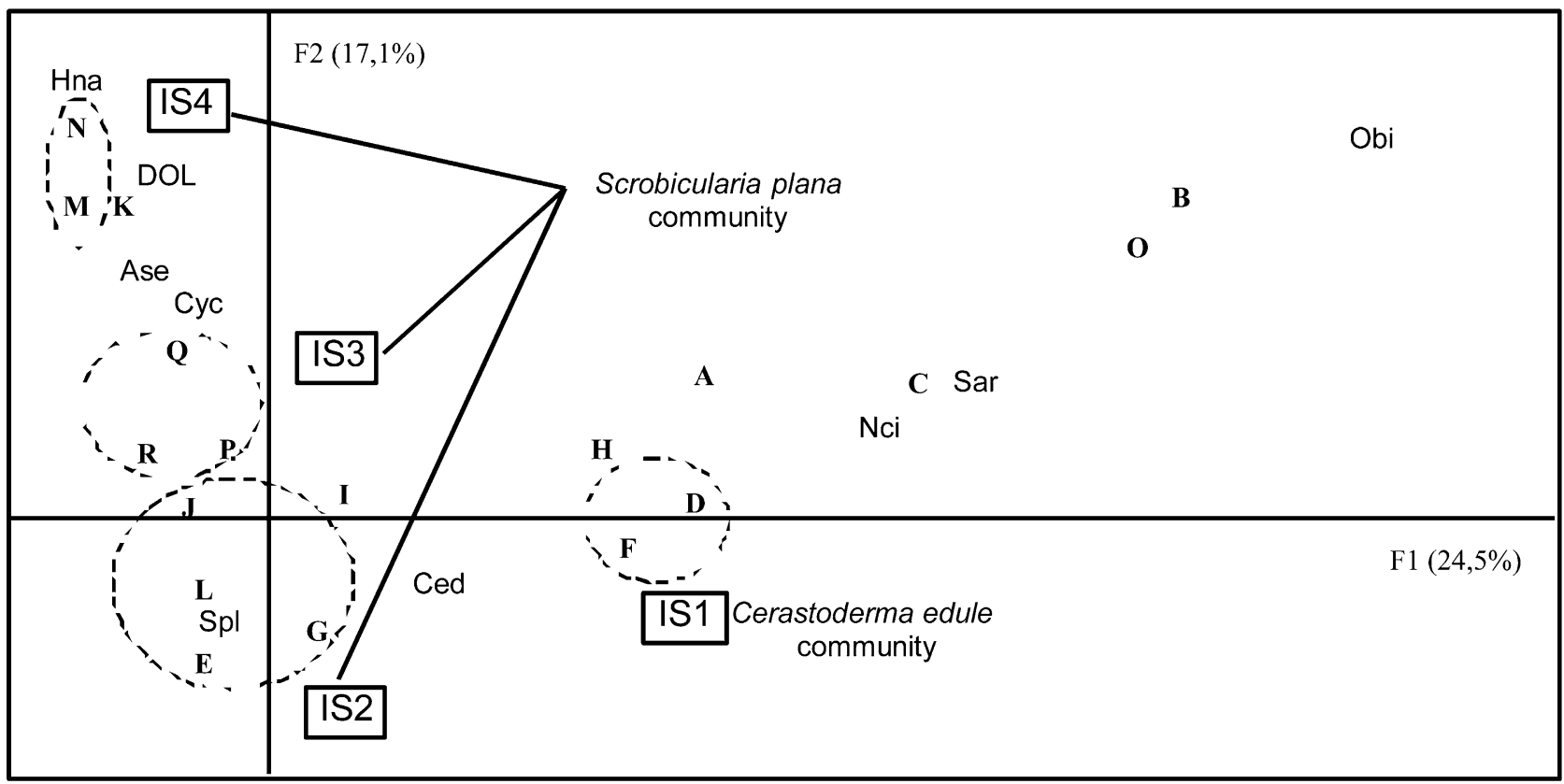

Fig. 5. Intertidal stations and significant species on the first two axes of correspondence analysis. The dashed circles represent the groups identified by hierarchical classification (Fig. 3). Hna, Haminoea navicula; DOL, Dolichopodidae; Ase. Abra segmentum; Cyc, Cyathura carinata; Spl, Scrobicularia plana; Ced, Cerastoderma edule; Nci, Nephtys cirrosa; Sar, Scoloplos armiger; Obi, Ophelia bicornis.

Table 1

Correlation tests using Spearman rank coefficient between location of stations on the correspondence analysis F1 axes and environmental parameters. The values in bold indicate a significant correlation at the $95 \%$ level

\begin{tabular}{lll}
\hline Environmental parameters & Factorial axes \\
\cline { 2 - 3 } & F1 intertidal & F1 subtidal \\
\hline Distance from the entrance & $\mathbf{0 . 8 0}$ & $\mathbf{- 0 . 9 5}$ \\
Mean rate of coarse sand-gravels & $\mathbf{0 . 7 8}$ & $\mathbf{- 0 . 5 6}$ \\
Mean rate of fine sand & 0.45 & 0.22 \\
Mean rate of silts & $\mathbf{- 0 . 7 8}$ & 0.51 \\
Mean median diameter & $\mathbf{0 . 8 3}$ & -0.44 \\
Mean sorting index & -0.45 & 0.28 \\
Mean rate of organic matter. & $\mathbf{- 0 . 8 0}$ & $\mathbf{0 . 5 2}$ \\
Mean interstitial temperature & $\mathbf{0 . 6 2}$ & \\
Mean water temperature & 0.35 & 0.39 \\
Mean salinity & $\mathbf{0 . 7 8}$ & $\mathbf{- 0 . 7 4}$ \\
\hline
\end{tabular}

Negative values on the plot were dominated by Scrobicularia plana (6.4\%). Correlation between the correspondence analysis axes and the environmental factors was tested through the calculation of Spearman rank coefficient (Bayed, 1991). The test showed that the F1 axis is correlated to substratum conditions, the distance from the entrance, salinity and interstitial temperatures Table 1.

\subsubsection{Subtidal zone}

In the subtidal zone, the data matrix combines 86 species and 15 stations. The AHC shows four distinct groups of stations Fig. 6. The SS1 group (stations 2 and 13) was characterised by an unstable fine sand (sand easily moved by currents), with sediment median diameter ranging from 220 to $325 \mu \mathrm{m}$ Fig. 4. Stations 5 and 6 (SS2 group) were characterised by two different sediment types; the sediment

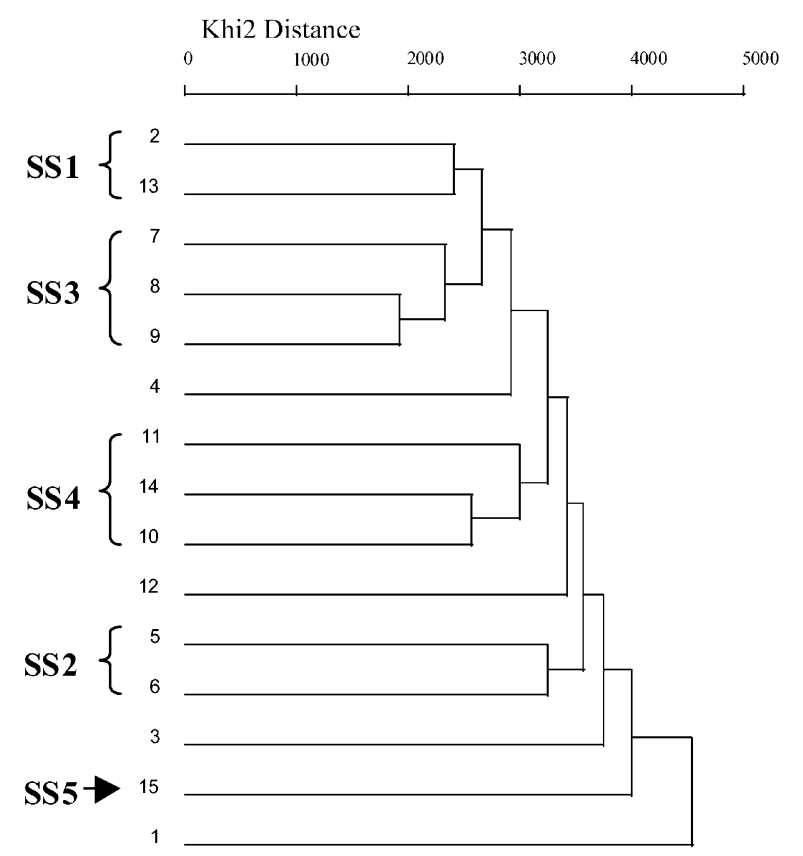

Fig. 6. Dendrogram produced from hierarchical cluster analysis, carried out on the subtidal assemblage data. Five groups are recognised (SS1, SS2, SS3, SS4 and SS5).

of station 5 was a compact sandy mud, whereas the sediment of station 6 was an unstable fine sand $(190 \mu \mathrm{m}>$ median diameter $>250 \mu \mathrm{m})$. The SS3 group was composed of stations 7, 8 and 9, which were located along the main channel (median diameter: 140-250 $\mu \mathrm{m}$; silt content: 10-30\%). The SS4 group was composed of stations 10, 11 (fine muddy sand) and 14 (sandy mud). SS5 (station 15), located upstream, was characterised by a heterogeneous biogenic 


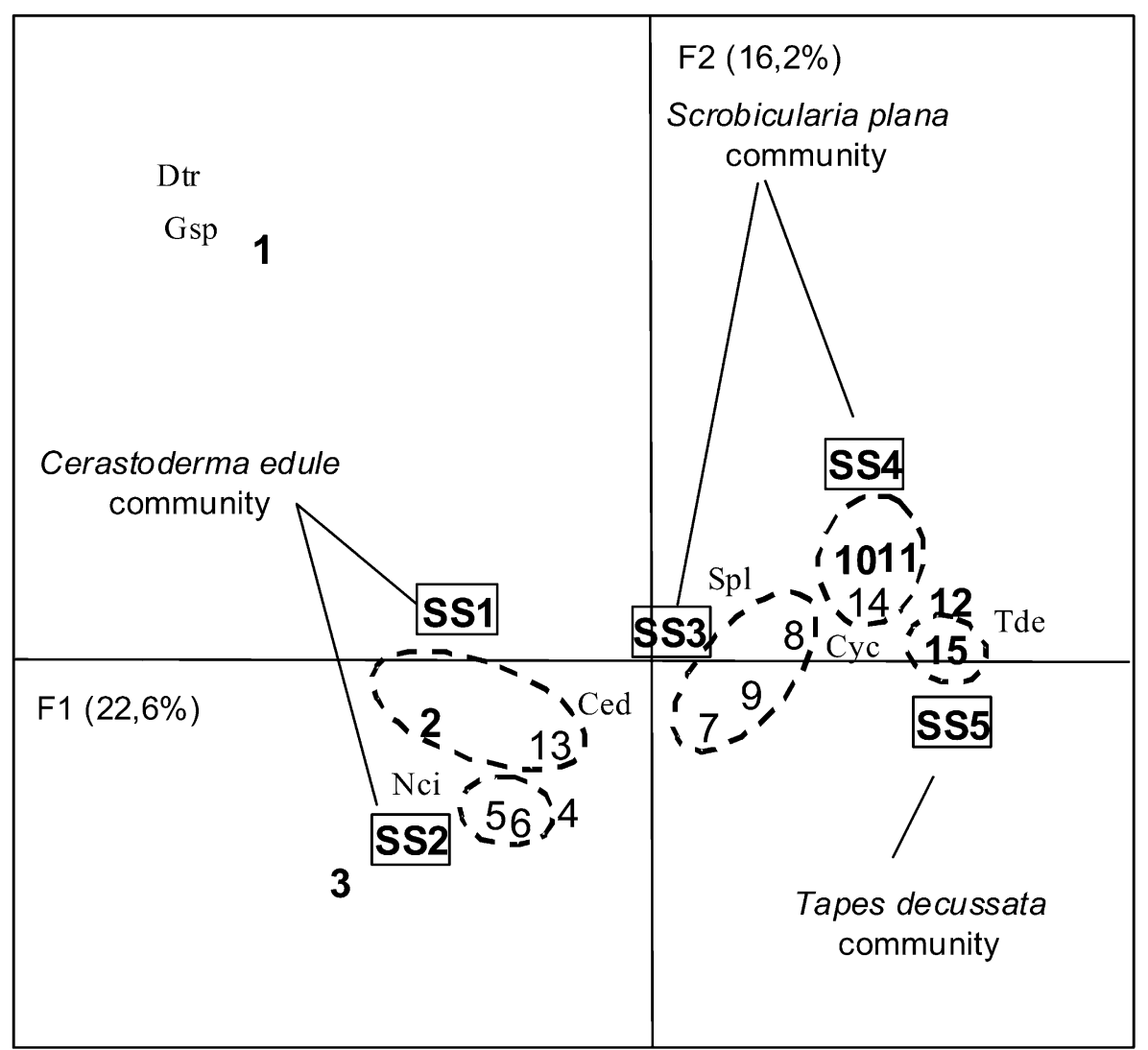

Fig. 7. Subtidal stations and significant species on the first two axes of correspondence analysis. The dashed circles represent groups identified by hierarchical classification (Fig. 6). Dtr, Donax trunculus; Gsp, Gastrosaccus spinifer; Nci, Nephtys cirrosa; Ced, Cerastoderma edule; Spl, Scrobicularia plana; Cyc, Cyathura carinata; Tde, Tapes decussata.

sand-mainly Cerastoderma edule and Scrobicularia plana shells-which occurs commonly in the inner part of the lagoon.

The FCA performed on these stations clearly differentiated the group of stations identified by cluster analysis Fig. 7. Two distinct groups of species, opposite along the F1 axis, controlled the distribution of these stations groups: (i) the bivalves Scrobicularia plana and Tapes decussata and the isopod Cyathura carinata (contributions $=12.4 \%, 8.6 \%$, $6.8 \%$, respectively) in the positive values, and (ii) the mysid Gastrosaccus spinifer (9.4\%), the polychaete Nephtys cirrosa $(8.1 \%)$ and the bivalves Cerastoderma edule $(7.2 \%)$ and Donax trunculus (7.3\%), in the negative values. The Spearman coefficient showed a significant correlation between F1 axis and (a) the distance from the entrance, (b) salinity, (c) coarse sand and gravel rates and (d) organic matter rate Table 1.

\subsection{Identification and communities structure}

Each group of stations identified by the AHC corresponds to an assemblage of species. The FDM index (Frequency $x$ Mean Dominance index) characterises each species of the particular assemblage. Table 2 gives the species composition for each assemblage of the intertidal and subtidal zones, the structural parameters and the diversity index. It also shows the dominant species and faunal affinities between assemblages.

\subsubsection{Intertidal zone}

The IS1 group can be identified as a Cerastoderma edule community, while IS2, IS3 and IS4 assemblages are considered as three subcommunities of a Scrobicularia plana community: the Cerastoderma edule subcommunity (IS2), the Heteromastus filiformis-Cyathura carinata subcommunity (IS3) and the Dolichopodidae subcommunity (IS4), respectively. In these four assemblages, the higher specific richness is associated with the higher abundance; in the Cerastoderma edule community, 71 species had a total abundance of 860 ind. $\mathrm{m}^{-2}$, while the other had less than 40 species and 450 ind. $\mathrm{m}^{-2}$. The Shannon-Weaver index was low and fluctuated between 1.45 bits (IS1) and 2.23 bits (IS3). The evenness ranged between 0.61 and 0.72 . It can be deduced that the Heteromastus filiformis-Cyathura carinata subcommunity (IS3) was the more structured.

\subsubsection{Subtidal zone}

Three communities can be identified: (i) the Cerastoderma edule community grouping Nephtys cirrosa (SS1) and Nassarius reticulatus (SS2) subcommunities; (ii) the Scrobicularia plana community (SS3 and SS4 groups) where the SS3 assemblage can be defined as a Cerastoderma 
Table 2

Faunal and structural characteristics of the macrozoobenthic assemblages recorded from the Merja Zerga lagoon. The highest values of the FDM index indicate the dominant species (in bold and underlined) in the respective assemblage type

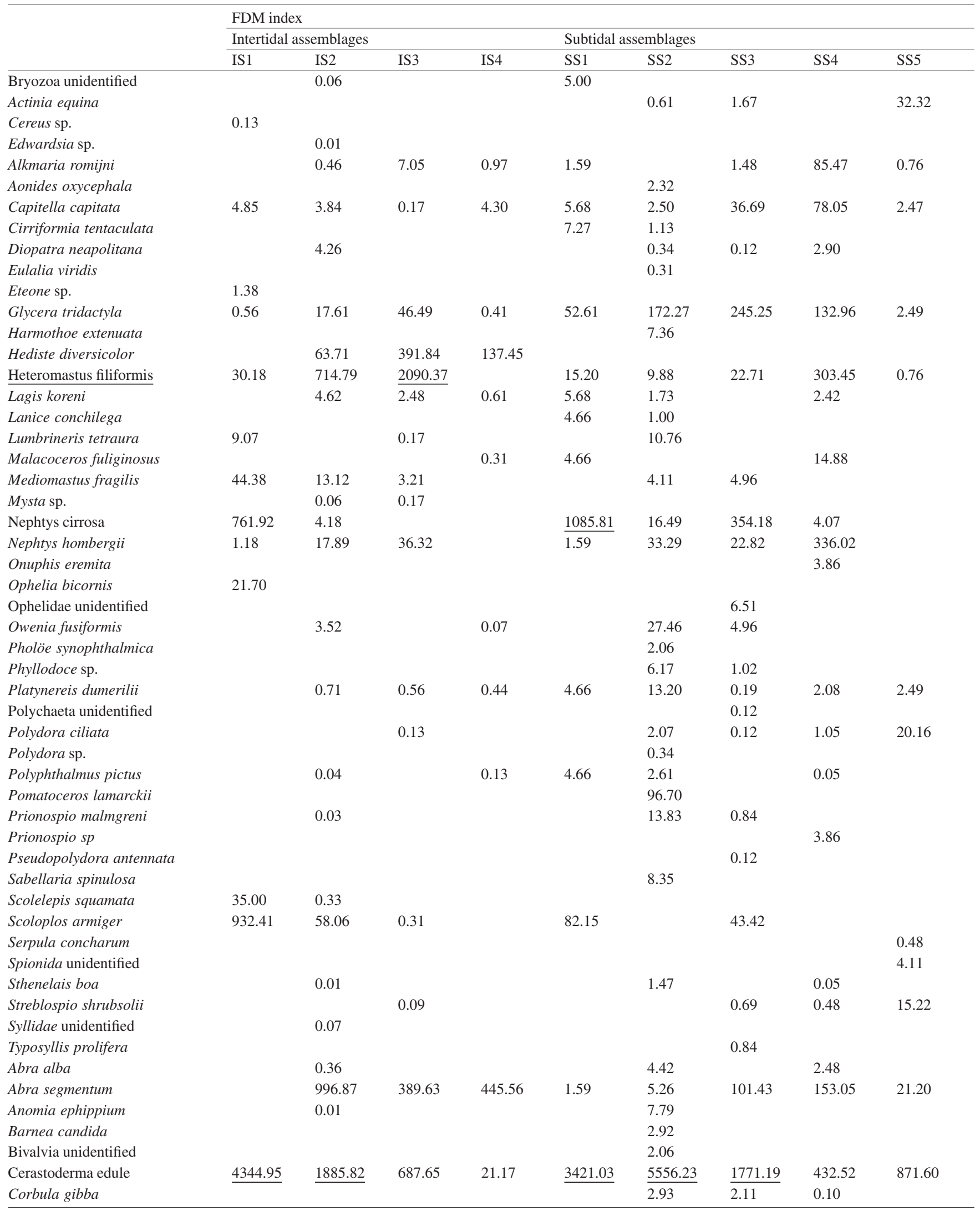


Table 2

(continued)

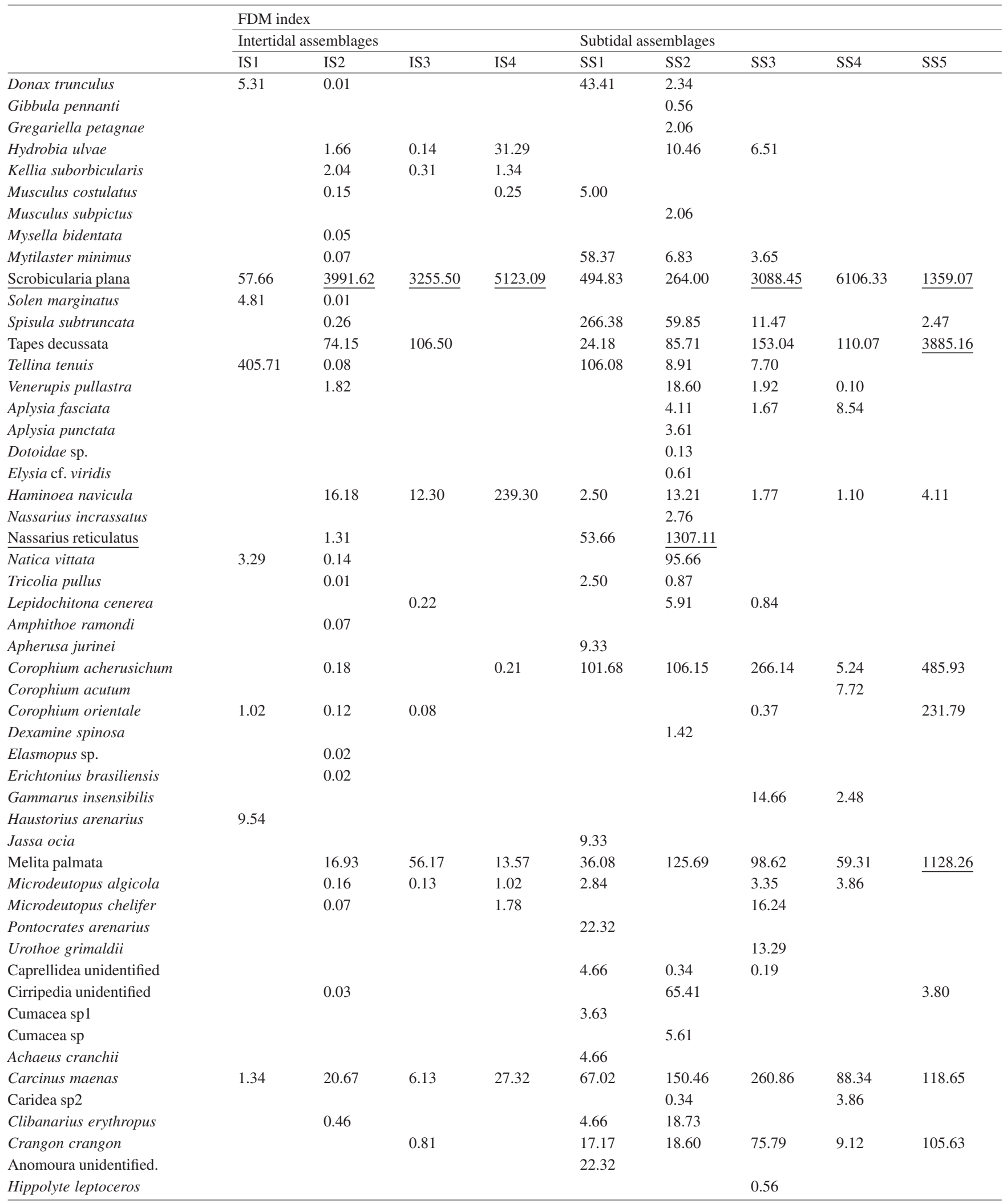


Table 2

(continued)

\begin{tabular}{|c|c|c|c|c|c|c|c|c|c|}
\hline & \multicolumn{9}{|c|}{ FDM index } \\
\hline & \multicolumn{4}{|c|}{ Intertidal assemblages } & \multicolumn{5}{|c|}{ Subtidal assemblages } \\
\hline & IS1 & IS2 & IS3 & IS4 & SS1 & SS2 & SS3 & SS4 & SS5 \\
\hline Hippolyte longirostris & & & & & & & 0.19 & & \\
\hline Macropodia rostrata & & & & & 4.66 & 0.13 & & & \\
\hline Palaemon serratus & & & & & & 5.33 & 9.02 & & \\
\hline Palaemonetes varians & & & & & & & & & 2.47 \\
\hline Penaeus kerathurus & & & & & 2.84 & & & & 0.76 \\
\hline Pinnotheres pisum & & 0.17 & & & & 27.02 & & & \\
\hline Pisa sp. & 0.13 & & & & & & & & \\
\hline Processa sp. & & 0.01 & & & 2.50 & 0.34 & & & \\
\hline Sirpus zariquieyi & 6.06 & & & & & & & & \\
\hline Upogebia pusilla & & 3.17 & 2.29 & & & & & & \\
\hline Cyathura carinata & 0.93 & 418.09 & $\underline{1845.19}$ & 470.88 & 356.82 & 86.16 & 651.55 & 759.33 & 670.77 \\
\hline Idotea chelipes & & 22.52 & $\overline{33.72}$ & 11.45 & 6.25 & 42.10 & 334.53 & 13.80 & 135.24 \\
\hline Idotea emarginata & & & & & & 1.55 & & & \\
\hline Parachiridotea panousei & 1.06 & & & & 22.32 & & & & \\
\hline Sphaeroma bocqueti & 1.34 & & & & & & 1.67 & 7.72 & \\
\hline Sphaeroma rugicauda & & & & & & & & & 1.45 \\
\hline Sphaeroma sp. & 3.70 & & & & 61.82 & 2.61 & 8.68 & & \\
\hline Sphaeromatidea sp & & & & & 4.66 & & & & \\
\hline Gastrosaccus spinifer & 1.29 & & & & 202.31 & & 6.51 & & \\
\hline Mesopodopsis slabberi & & & & & & & 0.37 & & \\
\hline Paramysis sp. & & 0.07 & & & 118.64 & 2.11 & 11.47 & 25.93 & 2.47 \\
\hline Tanais dulongii & & 0.58 & & 0.07 & & & & & \\
\hline Crinoïdea unidentified & & & & & 2.50 & & & & \\
\hline Ophiuroidea unidentified & & & & & 4.66 & 6.17 & & & \\
\hline Paracentrotus lividus & & 0.01 & & & & 0.65 & & & \\
\hline Echiuria unidentified & & & 0.27 & & & & & & \\
\hline Chironomidae & & 0.11 & 5.52 & 8.08 & & & 3.64 & 15.56 & \\
\hline Dolichopodidae & 0.95 & 385.20 & 2.67 & $\underline{1501.87}$ & & & 6.88 & & \\
\hline Syrphidae & & 4.91 & & & & & & & \\
\hline Tabanidae & & 0.78 & & 26.28 & & & & & \\
\hline Nemertea unidentified & 106.77 & 13.71 & 70.42 & 18.86 & 539.23 & 292.40 & 222.40 & 67.41 & 307.60 \\
\hline Oligochaeta unidentified & & & 0.13 & & & & & & \\
\hline Plathelmintha unidentified & & 0.33 & 0.13 & & & & & & \\
\hline Turbellaria sp1 & & 0.27 & & & & & 0.84 & & \\
\hline Turbellaria sp2 & & & 0.14 & & & & & & \\
\hline Anguilla anguilla & & & & & & & & 102.53 & 12.34 \\
\hline Hippocampus hippocampus & & & & & & 0.13 & & & \\
\hline Lophius sp. & & & & & 1.59 & & & & 1.94 \\
\hline Pisces unidentified & & 0.92 & & & & & & & \\
\hline Pomatoschistus microps & & 0.21 & 0.31 & & 7.93 & 9.86 & 4.96 & 3.18 & 0.48 \\
\hline Solea senegalensis & & & & & 4.66 & 16.97 & 51.13 & 2.04 & 2.28 \\
\hline Anoplodactylus pygmaeus & & 0.01 & & & & & & & \\
\hline Sipuncula unidentified & & & & & 8.85 & & & & \\
\hline \multirow[t]{4}{*}{ Tunicata unidentified } & & 0.37 & 0.07 & & & & & & \\
\hline & \multicolumn{9}{|c|}{ Structure and diversity measures } \\
\hline & \multicolumn{4}{|c|}{ Intertidal assemblages } & \multicolumn{5}{|c|}{ Subtidal assemblages } \\
\hline & IS1 & IS2 & IS3 & IS4 & SS1 & SS2 & SS3 & SS4 & SS5 \\
\hline Total specific richness & 29 & 71 & 39 & 28 & 56.0 & 80.0 & 59.0 & 42.0 & 33.0 \\
\hline Mean specific richness & 5 & 9.88 & 9.13 & 6.38 & 13.4 & 28.3 & 14.8 & 13.5 & 17.5 \\
\hline Mean abundance & 198.46 & 866.08 & 477.28 & 259.54 & 79.3 & 712.0 & 328.7 & 601.3 & 629.5 \\
\hline Mean diversity & 1.45 & 1.86 & 2.23 & 1.67 & 2.6 & 2.3 & 2.4 & 1.8 & 2.5 \\
\hline Mean evenness & 0.63 & 0.61 & 0.72 & 0.70 & 0.7 & 0.5 & 0.7 & 0.5 & 0.6 \\
\hline
\end{tabular}


Table 3

Trophic structure, in terms of total abundance over a year cycle, of the benthic communities recorded from the Merja Zerga lagoon. See text for the trophic guilds abbreviations

\begin{tabular}{|c|c|c|c|c|c|}
\hline \multirow[t]{2}{*}{ Trophic guilds } & \multicolumn{2}{|l|}{ Intertidal zone } & \multicolumn{3}{|l|}{ Subtidal zone } \\
\hline & C. edule community & S. plana community & C. edule community & S. plana community & T. decussata community \\
\hline$\overline{\mu B}$ & - & 4 & 10 & - & - \\
\hline $\mathrm{C}$ & 101 & 799 & 570 & 186 & 127 \\
\hline DS & 74 & 11,279 & 3340 & 6313 & 411 \\
\hline Dt & 6 & 2171 & 533 & 185 & 801 \\
\hline $\mathrm{H}$ & - & 1 & 15 & 3 & - \\
\hline DSS & 253 & 1402 & 99 & 137 & 2 \\
\hline $\mathrm{N}$ & - & 12 & 648 & - & - \\
\hline S & 854 & 3313 & 5034 & 379 & 1176 \\
\hline
\end{tabular}

edule subcommunity; (iii) the Tapes decussata-Melita palmata community (SS5 group). On the upstream gradient, the species richness, low in SS1 (56 species), was maximal in SS2 (80 species). Species richness decreases along the gradient to reach a minimum (33 species in SS5) upstream. Abundance values did not show such a pattern over the upstream-downstream gradient. The Shannon-Weaver index $\left(H^{\prime}\right)$ varied between 1.83 bits (SS4) and 2.56 bits (SS1).

\subsection{Trophic structure}

The trophic structure of the benthic communities was alternatively dominated by the suspension feeders and the selective deposit feeders Table 3. The C. edule and T. decussata communities were dominated by suspension feeders while the Scrobicularia plana community was dominated by surface deposit feeders. The other trophic groups were low in terms of number of species and abundance, both in the intertidal and subtidal zones.

\subsection{Comparison between intertidal and subtidal communities}

The Sokal-Sneath index (Legendre and Legendre, 1979) showed high similarities ( $>60 \%$ ) between the species assemblages Fig. 8a. This fact indicates that no ecotone is present. The Chi-square comparison Fig. 8b confirmed that the nine identified assemblages were organised in three communities, along the upstream gradient: the $C$. edule community (IS1, SS1 and SS2), the S. plana community (IS2, IS3, IS4, SS3 and SS4) and the T. decussata community (SS5).

The Dimo model Fig. 9) distinctly separates the subtidal from the intertidal assemblages. According to this model, the intertidal communities show type 2 dynamics (i.e. evenness type) in which the changes observed in the diversity pattern are mainly controlled by a change in species number while evenness remains unchanged. On the other hand, the pattern shown by the subtidal communities is a type 4 pattern (i.e. non- type: all three parameters change).

The Fig. 10 illustrates the succession of the communities and assemblages, and the range variation of salinity and silt content along the upstream-downstream gradient both in intertidal and subtidal zones. The C. edule community (IS1, $\mathrm{SS} 1, \mathrm{SS} 2$ ) can be considered as a marine community under a continental influence. The S. plana community (IS2, IS3, IS4, SS3, SS4) occupied the more muddy areas (silt content $>20 \%$ ) and it contained taxa defined as brackish water species (e.g. Alkmaria romijni, Abra segmentum, Streblospio shrubsolii, Hediste diversicolor, etc.) and species preferring high organic matter content of the sediment (Heteromastus filiformis, Capitella capitata). In the subtidal zone, the $T$. decussata community (SS5) occupied the upstream biogenic coarser sediments.

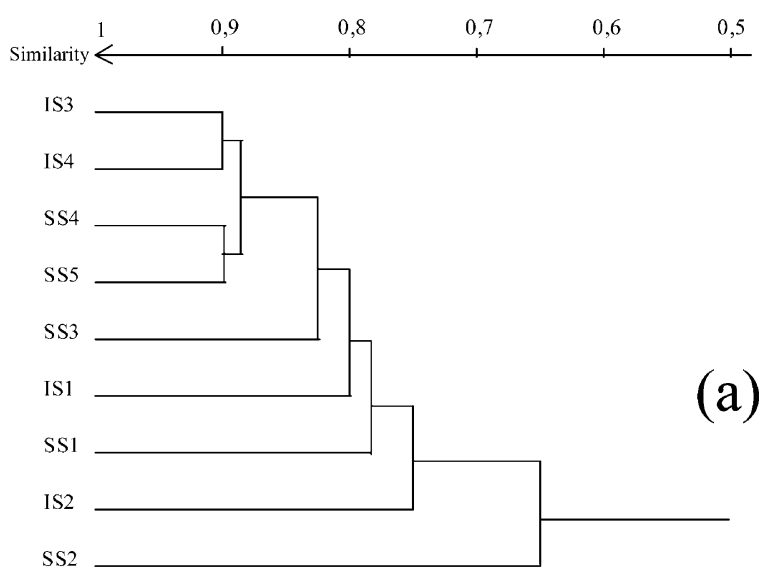

$$
0 \stackrel{\text { Khi2 Distance }}{\longleftarrow} 200
$$

$\mathbf{T d}$

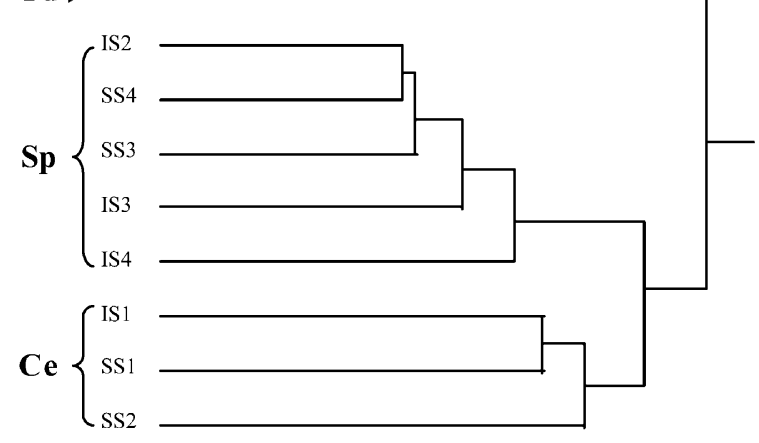

(b)

Fig. 8. Dendrograms produced by Hierarchical Cluster Analysis using Sokal-Sneath index (a) and Khi2 index (b). Tp, Tapes decussata community; $\mathrm{Sp}$, Scrobicularia plana community; Ce, Cerastoderma edule community. 


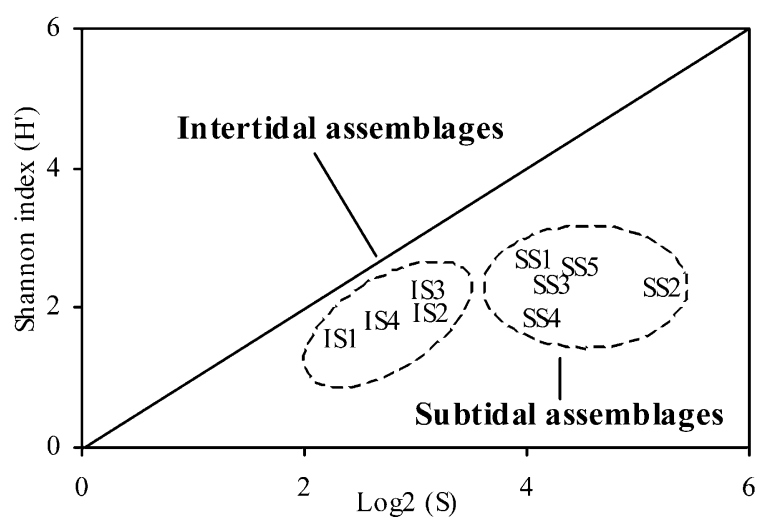

Fig. 9. Simultaneous representation of the specific richness $\log _{2} S$, of the Shannon index $H^{\prime}$ and the evenness $\alpha$. The $Q$ index is defined as the vector length from the origin to the point of the station. This index is lower in the intertidal stations.

\section{Discussion}

Large differences in communities structure between intertidal and subtidal zones characterised the macrobenthic organisation in the Merja Zerga lagoon. The nine identified assemblages were grouped into three communities. The C. edule community was better represented in the subtidal zone where it occupied large areas, compared to the intertidal where the S. plana community dominated. The Tapes decussata community was only identified in the subtidal area.

The species structure of these communities varied upstream without marked discontinuities and ecotones. Changes were gradual, resulting essentially in modifications of the relative abundance of species, independently of species composition. This results in a succession of assemblages in a biocoenotic continuum as demonstrated by the high similarities $(>60 \%)$ between assemblages and correspondence analysis.

Ecological gradients appeared to be an expression of edaphic and hydrological factors acting differently in the intertidal and subtidal zones Fig. 10. In the intertidal zone, the macrofaunal communities were primarily controlled firstly by the edaphic parameters (mainly silt content) and secondly by the hydrology. In the subtidal zone, the hydrological parameters were the main controlling factors, explaining the distribution of the stations along the F1 axis of the correspondence analysis. The edaphic parameters contributed only at a second level, explaining the structure of subcommunities.

The upstream zonation in the qualitative and the quantitative structures of the benthic communities at Merja Zerga lagoon is a well-known pattern in most semi-enclosed inshore ecosystems (lagoons and estuaries). Many ecological studies at different latitudes have pointed out factors controlling such a zonation: salinity has been considered generally as the main ecological factor (Kiener, 1978), presumably because of its variability but also because of its easy measurement (Guélorget and Perthuisot, 1983). This is why salinity was often used to elaborate classifications and typolo- gies of coastal environments. However, some authors have emphasised that salinity is not the main controlling factor of the spatial distribution of species in brackish environment (Guélorget and Perthuisot, 1983).

Most of the macrobenthic species recorded from the Merja Zerga lagoon showed a large spatial distribution and were not characteristic of a single habitat. Such a pattern agrees better with the concept of a continuum of communities along an environmental gradient (Mills, 1969) than the concept of discrete communities as distinct assemblages of species defined by Thorson (1957). The biological continuum and the absence of ecotonal zones seem to be true characteristics of semi-closed coastal ecosystems and of estuaries in particular. Indeed, this pattern was described in various estuaries: the Bou Regreg estuary on the Moroccan Atlantic coast (Elkaim, 1976a,b, 1977), the Ria of Foz (Junoy and Viéitez, 1990) on the Spanish coast of Galicia, the Blavet, Scorff and Vilaine estuaries, France (Le Bris and Glémarec, 1996), the Loire estuary, France (Robineau, 1987) and the Ems and Wesers estuaries of the Wadden Sea (Michaelis, 1981). The explanation of this observation is probably the high tolerance of the recorded benthic species to large physico-chemical fluctuations (Wolff, 1973). However, the use of appropriate statistical analysis enabled identification of assemblages along the ecological continuum. Such assemblages are found in areas under the control of a particular factors, shifting along the downstream gradient (Hily, 1976). Robineau (1987) identified a Boccardia ligerica and insect larvae community, a Corophium volutator community (with three subcommunities) and a Donax vittatusBathyporeia pelagica community in relation to salinity gradient. Junoy and Viéitez (1990) identified a biological continuum in the Foz Ria estuary with three communities corresponding, respectively, to the 'boreal lusitanian Tellina community' (Thorson, 1957), the 'biocoenosis of sands and slightly muddly mediolittoral sands' (Pérès and Picard, 1964) and the 'Cardium (i.e. Cerastoderma) edule-Scrobicularia plana community' of Thorson (1957). On the Moroccan Atlantic coast, in the Bou Regreg estuary, an open system situated $120 \mathrm{~km}$ south of Merja Zerga lagoon, five communities were identified on upstream-downstream succession (ElKaim, 1976a,b, 1977): Corophium volutator community, Corophium orientale community, Scrobicularia plana community, Cerastoderma edule community and a Donax-Eocuma community. While the geomorphological and hydrological characteristics of these two systems are different, the patterns of the spatial organisation of the macrobenthic communities are similar. The dominant species characterising the benthic communities of Merja Zerga lagoon are also dominant species in many European estuaries, for example the Loire estuary (France) (Robineau, 1987) and the Ria of Foz (Spain) (Junoy and Viéitez, 1990). The benthic communities of the Merja Zerga lagoon can be considered as belonging to the Cerastoderma edule-Scrobicularia plana community defined by Thorson (1957), also identified in the Galician Ria of Foz (Spain) (Junoy and Viéitez, 1990). It can 


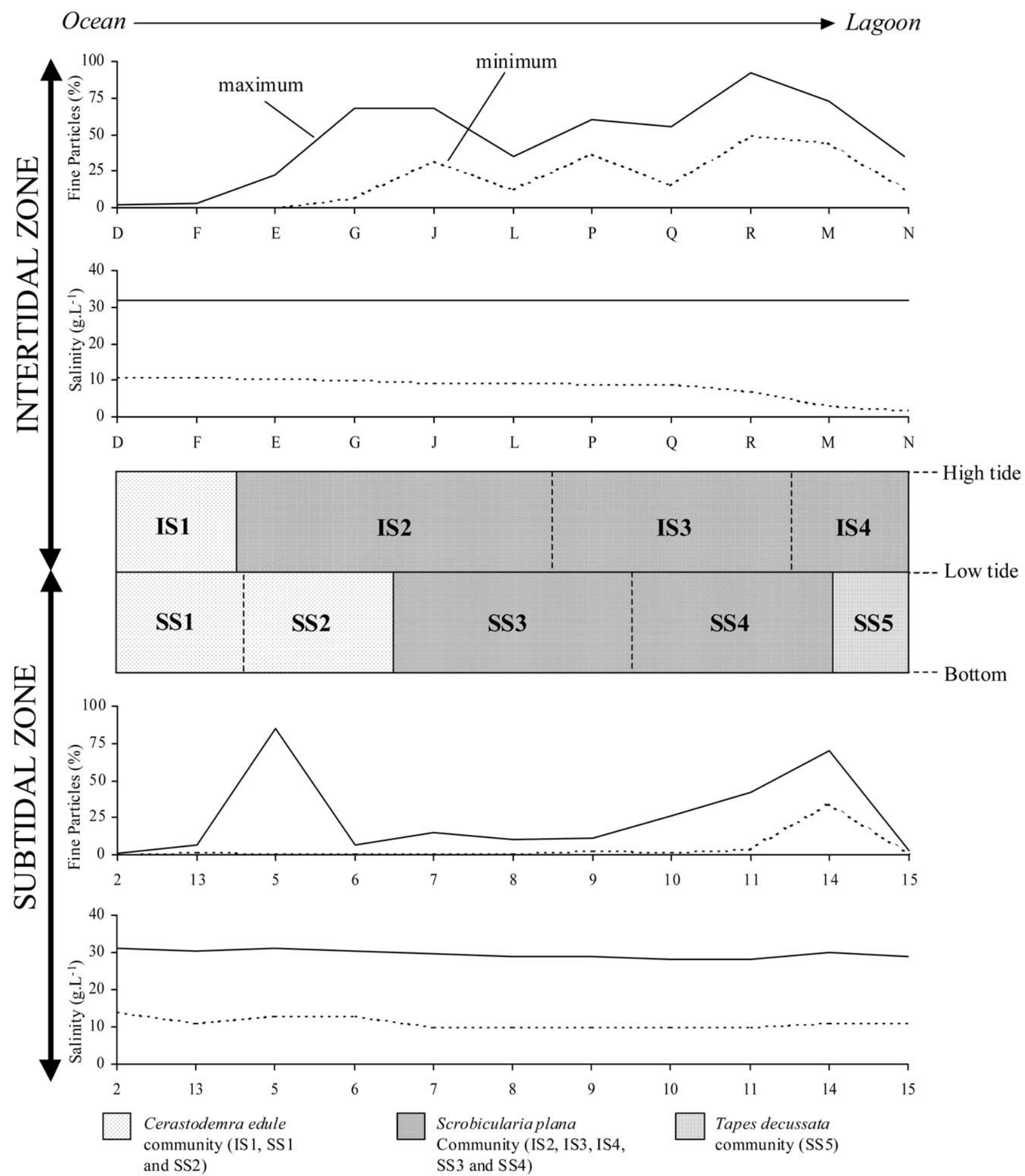

Fig. 10. Schematic representation of the benthic assemblages identified in the Merja Zerga lagoon with reference to variation during an annual cycle of fine particle content of the sediment and salinity (minimum - maximum) at each station.

therefore be concluded that Merja Zerga is a lagoon functioning as an estuarine system.

In terms of taxonomic and trophic structures of the benthic communities, Merja Zerga lagoon shows some specific features. One is the higher species richness observed in the subtidal zone compared to the intertidal zone. In North Atlantic coastal ecosystems, the opposite situation is often ob- served to be true (Marques et al., 1993; Bachelet et al., 1996). The trophic structure analysis demonstrated that the $S$. plana and $C$. edule communities are functionally different. Surface deposit feeders dominate the former while suspension feeders dominate the latter. Suspension feeders also dominate the $T$. decussata community. The dominance of one of these trophic groups has previously been demonstrated to be driven 
by hydrodynamics and the sediment grain size (Bachelet, 1981; Dauvin, 1988). The analysis shows that when the $S$. plana community has an extension in the subtidal zone, a decrease in terms of abundance and number of trophic groups was noted. Conversely, the extension in the intertidal zone of the $C$. edule community results in a decrease in terms of abundance and number of trophic groups. The dominance of the suspension feeders in the subtidal area underlines the major role of tidal currents in the macrobenthic systems, preventing sedimentation at low tides. At high tide, the low currents favour the sedimentation on the intertidal flats, which favours the deposit feeders.

This first study of the benthic ecosystem of the Merja Zerga lagoon is a baseline for further studies on the other ecosystem components. The lagoon is of high value in terms of exploitation of the natural resources and for nature conservation. The benthic communities, which supply food for exploited species (fishes) and protected species (birds), are rich, both in terms of biodiversity and abundance. The study of the temporal variability of these assemblages and the identification of the main interactions with the upper (megafauna, avifauna) and lower components (primary production) of the ecosystem will be the next step to help achieve sustainable development and managed conservation.

\section{Acknowledgements}

The authors gratefully acknowledge M. Boubkari for his technical assistance in the field and in the laboratory. Two anonymous referees must be cordially thanked for their critical review and language correction that improved readability.

\section{References}

Amanieu, M., Ferraris, J., Guélorget, O., 1980. Organisation et évolution des peuplements des lagunes littorales. Application à la macrofaune benthique des étangs palavasiens. In: Barbault, R., Blandin, P., Meyer, J.A. (Eds.). Recherches d'écologie théorique. Les stratégies adaptatives. Maloin, Paris, pp. 251-277.

Bachelet, G., 1981. Données préliminaires sur l'organisation trophique d'un peuplement benthique marin. Vie Milieu 31 (3-4), 205-213.

Bachelet, G., de Mountaudouin, X., Dauvin, J.-C., 1996. The quantitative distribution of subtidal macrozoobenthic assemblages in Arcachon bay in relation to environmental factors: a multivariate analysis. Estuar. Coast. Shelf S. 42, 371-391.

Bayed, A., 1991. Etude écologique des écosystèmes de plages de sable fin de la côte atlantique marocaine. Modèle de zonation, biotypologie, dynamique de population. Doctorat d'Etat Thesis. Université Mohammed V, Rabat, 229 p.

Bayed, A., 2003. Influence of morphodynamic and hydroclimatic factors on the macrofauna of Moroccan sandy beaches. Estuar. Coast. Shelf S. 56, $1-12$.

Bazaïri, H., Bayed, A., 1998. Recherches sur la biotypologie des Mollusques de la lagune de Moulay Bousselham, Maroc. Rapp. Comm. int. Explor. Scient. Mer Médit. 35, 520-521.

Beaubrun, P.-C., 1976. La lagune de Moulay Bousselham: étude hydrologique et sédimentologique. Bull. Inst. Sci. 1, 5-37.
Benzecri, J.P., 1973. Analyse des données-(2) Analyse des correspondances. Dunod, Paris.

Bidet, J.C., Carruesco, C., Gensous, B., 1977. Un milieu sédimentaire actuel: la lagune de Moulay-Bou-Salham (côte atlantique marocaine). Bull. Inst. Géol. Bassin d'Aquitaine, Bordeaux 22, 189-230.

Carruesco, C., 1989. Genèse et évolution de trois lagunes du littoral atlantique depuis l'holocène: Oualidia-Moulay Bousselham (Maroc) et Arcachon (France). Doctorat d'Etat Thesis. Université de Bordeaux I, Tome 1 et $2,485 \mathrm{p}$.

Chassé, C., Glémarec, M., 1976. Principes généraux de la classification des fonds pour la cartographie bio-sédimentaire. J. Rech. Océanogr. 1 (3), $1-18$.

Dakki, M., 1985. Sur le choix des données en biotypologie des eaux courantes par l'analyse factorielle des correspondances. Bull. Ecol. 16 (4), 285-296.

Dauvin, J.C., 1988. Structure et organisation trophique du peuplement des sables grossiers à Amphioxus lanceolatus-Venus fasciata de la baie de Morlaix (Manche occidentale). Cah. Biol. Mar. 29, 163-185.

El Agbani, M.A., 1997. L'hivernage des Anatidés au Maroc. Principales espèces et zones humides d'importance majeure. Doctorat d'Etat Thesis. Université Mohammed V-Agdal, Rabat, 168 p.

Elkaim, B., 1976a. Bionomie et écologie des peuplements des substrats meubles d'un estuaire atlantique marocain : l'estuaire du Bou Regreg. IUnités indicatrices infralittorales. Vie Milieu 26 (1-B), 107-169.

Elkaim, B., 1976b. Bionomie et écologie des peuplements des substrats meubles d'un estuaire atlantique marocain : l'estuaire du Bou Regreg. IIUnités indicatrices peu liées à l'étagement ou médiolittorales. Vie Milieu 26 (2-B), 199-241.

Elkaim, B., 1977. Bionomie et écologie des peuplements des substrats meubles d'un estuaire atlantique marocain: l'estuaire du Bou Regreg. III- Unités indicatrices supralittorales ou en position supralittorale. Vie Milieu 27 (1-B), 27-83.

Glémarec, M., 1964. Bionomie benthique de la partie orientale du golfe du Morbihan. Cah. Biol. Mar. 5, 33-96.

Glémarec, M., 1986. Ecological impact of an oil spill: utilization of biological indicators. Wat. Sci. Tech. 18, 203-211.

Guélorget, O., Perthuisot, J.P., 1983. Le domaine paralique. Expressions géologiques, biologiques et économiques du confinement. Trav. Lab. Géologie, Ecole Norm. Sup., Paris 16, 136 p.

Hily, C., 1976. Ecologie benthique des pertuis charentais. Doctorat $3^{\text {ème }}$ Cycle Thesis. Université de Bretagne Occidentale, Brest, 236 p.

Hily, C., Bouteille, M., 1999. Modifications of the specific diversity and feeding guilds in an intertidal sediment colonized by an eelgrass meadow (Zostera marina) (Brittany, France). C.R. Acad. Sci., Paris, Sciences de la vie 322, 1121-1131.

Junoy, J., Viéitez, J.M., 1990. Macrozoobenthic community structure in the Ria de Foz, an intertidal estuary (Galicia, northwest Spain). Mar. Biol. 107, 329-339.

Kiener, A., 1978. Ecologie, physiologie et économie des eaux saumâtres. Masson, Paris.

Le Bris, H., Glémarec, M., 1996. Marine and brackish ecosystems of south Brittany (Lorient and Vilaine Bays) with particular reference to the effect of the turbidity maxima. Estuar. Coast. Shelf S. 42, 737-753.

Lebart, L., Morineau, A., Fenelon, J.P., 1982. Traitement des données statistiques. Dunod, Paris.

Legendre, L., Legendre, P., 1979. Ecologie numérique. 1. Le traitement multiple des données écologiques; 2. La structure des données écologiques. Masson, Paris.

Marques, J.C., Rodrigues, L.B., Nogueira, A.J.A., 1993. Intertidal macrobenthic communities structure in the Mondego estuary (Western Portugal): reference situation. Vie Milieu 43 (2-3), 177-187.

Michaelis, H., 1981. Intertidal benthic animal communities of the estuaries of the rivers Ems and Weser. Mar. Zool. 4, 158-188. 
Mills, E.L., 1969. The community concept in marine zoology with comments on continua and instability in some marine communities: a review. J. Fish. Res. Bd. Can. 26, 1415-1428.

Pérès, J.M., Picard, J., 1964. Nouveau manuel de bionomie benthique de la Méditerranée. Rec Trav. Stat. Mar. Endoume 31, 1-137.

Picard, J., 1965. Recherches qualitatives sur les biocoenoses marines des substrats meubles dragables de la région marseillaise. Rec Trav. Stat. Mar. Endoume 52 (36), 1-160.

Qninba, A., 1999. Les limicoles (Aves, Charadrii) du Maroc: synthèse sur l'hivernage à l'échelle nationale et étude phénologique dans le site Ramsar de Merja Zerga. Université Mohammed V-Agdal, Rabat. Thèse Doctorat d'État, 206 p
Quinghong, L., 1995. A model for species diversity monitoring at community level and its application. Environ. Monit. Assess. 34, 271-287.

Robineau, B., 1987. Caractérisation des peuplements macrozoobenthiques de l'estuaire de la Loire. Vie Milieu 37 (2), 67-76.

Shepard, F.P., 1954. Nomenclature based on sand-silt-clay ratios. J. Sedim. Petrol. 24, 151-158.

Thorson, G., 1957. Bottom communities (sublittoral or shallow shelf). Mem. Geol. Soc. Am. 67, 461-534.

Wolff, W.J., 1973. The estuary as a habitat. An analysis of data on the soft-bottom macrofauna of the estuarine area of the rivers Rhine, Meuse and Scheldt. Zool. Verhand. 126, 1-242. 